Munkhjargal Dashnyam ${ }^{1 *}$, Oyuntsetseg Janchiv², Ulambayar Renchinhand", Ganbaatar Jamsranjav²

Scientific paper ISSN 0351-9465, E-ISSN 2466-2585

${ }^{1}$ Defenve university of Mongolia, Department of Mathematics and Computer Technology, Ulan Bator, Mongolia, ${ }^{2}$ Institute of Chemistry and Chemical technology, of Mongolian Academy of Sciences, Ulan Bator, Mongolia

\title{
The investigation of the effect of relevant parameters of Mongolian natural zeolites for ammonium ion removal from aqueous solution
}

\begin{abstract}
Our study investigated the potential of natural tseolite for ammonium ions removal from aqueous solution. In batch study, the effect of relevant parameters such as $\mathrm{pH}$, adsorbent dosage, contact time and initial ammonium concentration. Also, the effect $\mathrm{pH}$ investigated on ammonium removal of aqueous solutions. The removal capacity of clinoptilolite increased by 15 minutes during our experiment.

The Langmuir and Freundlich model were applied to describe the equilibrium isotherms for ammonium uptake and the Freundlich model agree very well with experimental data. Based on the results, it can be concluded that the natural zeolite is suitable for removal of $\mathrm{NH}_{4}^{+}$ions wastewater.
\end{abstract}

Keywords: clinoptilolite, natural zeolites, ammonium ion, aqueous solution.

\section{INTRODUCTION}

Ammonia nitrogen contributes to accelerated eutrophication of lakes and rivers, dissolved oxygen depletion and fish toxicity in water. The most widely used traditional processes for ammonia removal are: air stripping, ion exchange and biological nitrification- denitrification. The efficiency of the process of air stripping, and biological nitrification- denitrification is significantly impaired by the low temperature during winter period. Ion exchange, therefore, is more competitive because of little influence of the low temperature during winter in Mongolia and particularly its relative simplicity of application and operation.

Clinoptilolite, one of natural zeolites, has been found very effective in removing ammonia from water by means of its excellent ion exchange capacity since the seventies of last century. Natural

\footnotetext{
${ }^{\star}$ Corresponding author: Munkhjargal Dashnyam E-mail: munkhjargal26@yahoo.com

Paper received: 24. 10. 2016.

Paper accepted: 26.11.2016.

Paper is available on the website: www.idk.org.rs/journal
}

zeolite is porous material with high cation exchange capacity (CEC), cation selectivity, higher void volume and great affinity for $\mathrm{NH}_{4}^{4}[1]$.

The general formula of a zeolite is follows:

$$
\left(\mathrm{M}_{x}^{+}, \mathrm{M}_{y}^{2+}\right)\left(\mathrm{Al} \mathrm{l}_{(x+2 y)} \mathrm{Si}_{n-(x+2 y)} \mathrm{O}_{2 n}\right) \bullet \mathrm{mH}_{2} \mathrm{O}
$$

Where $\mathrm{M}^{+}$and $\mathrm{M}^{2+}$ are monovalent and divalent cations such as $\mathrm{Na}^{+}, \mathrm{K}^{+}$and $\mathrm{Ca}^{2+}, \mathrm{Mg}^{2+}, \mathrm{Ba}^{2+}$ respectively. There are called the exchangeable cations. $\mathrm{Al}^{3+}$ and $\mathrm{Si}^{4+}$ are known as the structural cations, and they make up the framework of the structure with $\mathrm{O}[1]$. In several studies, authors have also reported the use of natural zeolite as a sorbent for trace metals, $\mathrm{N}$ compounds and cations [2-6]

The main objectives of this study were to investigate the effect of $\mathrm{pH}$, dosage of adsorbent and shaking time on ion exchange of $\mathrm{NH}_{4}{ }^{+}$by the natural Mongolian (Urgun) zeolite from aqueous solution and to determine the equilibrium isotherms.

In Mongolia, the Environment and metrology lab report shows, that wastewater treatment plant effluents contain much higher levels of ammonia than permitted [10]. Therefore, it is necessary to reduce the ammonium contents (Figure 1). 


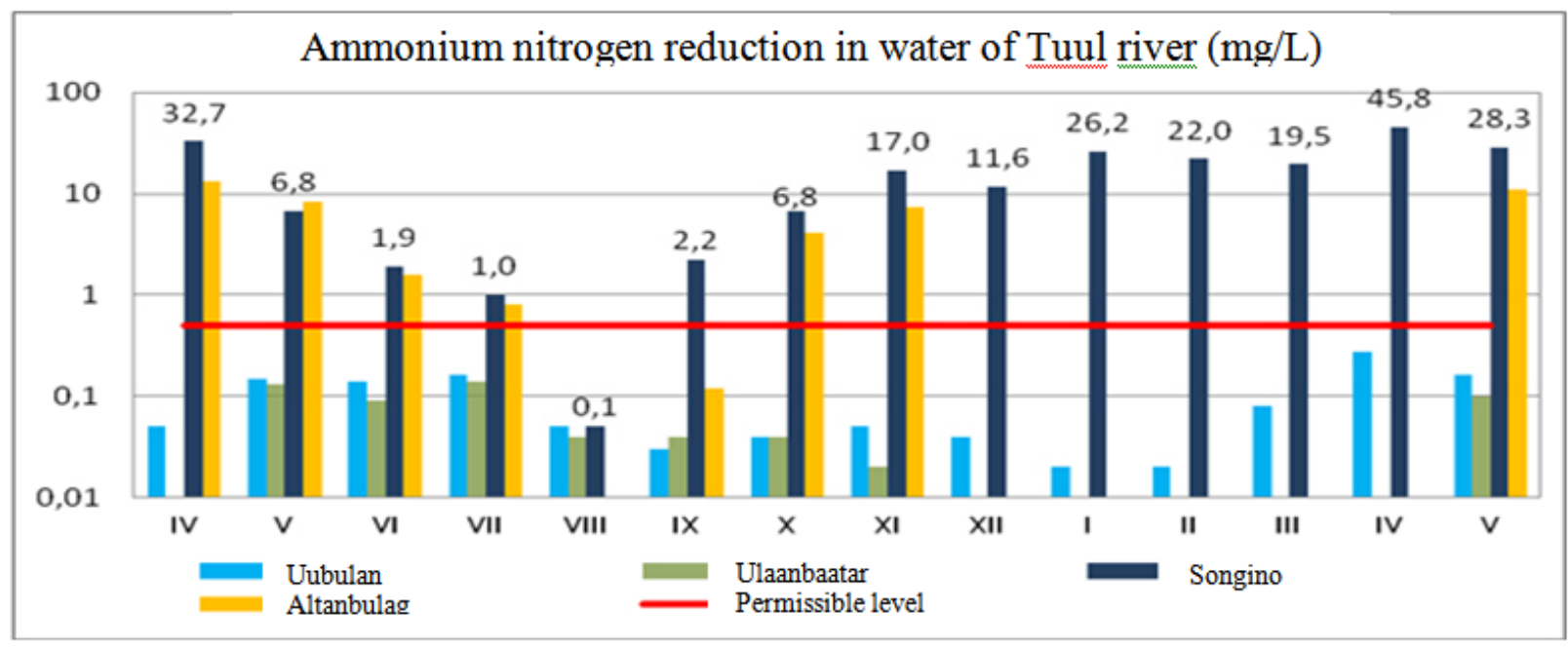

Figure 1 - Ammonium nitrogen reduction in water of Tuul River (mg/l)

\section{EXPERIMANTAL}

The clinoptilolite used as ion exchanger in the experiments was obtained from Mongolia deposit, in the province of Dornogovi. The chemical composition of the clinoptilolite used in the study is shown in Table 1.

Table 1 - Chemical composition of clinoptilolite

\begin{tabular}{|c|c|c|c|c|c|c|c|c|c|c|}
\hline Component & $\mathrm{SiO}_{2}$ & $\mathrm{TiO}_{2}$ & $\mathrm{Al}_{2} \mathrm{O}_{3}$ & $\mathrm{Fe}_{2} \mathrm{O}_{3}$ & $\mathrm{CaO}$ & $\mathrm{MgO}$ & $\mathrm{Na}_{2} \mathrm{O}$ & $\mathrm{K}_{2} \mathrm{O}$ & $\mathrm{P}_{2} \mathrm{O}_{5}$ & $\mathrm{LOI}$ \\
\hline$(\%)$ & 65.78 & 0.36 & 13.7 & 2.25 & 1.44 & 0.96 & 2.99 & 2.68 & 0.09 & 9.64 \\
\hline
\end{tabular}

The natural zeolite sample-was crushed in a mortar and sieved using $100 \mu \mathrm{m}$ sieve. The crashed -sample was dried in an oven at $105^{\circ} \mathrm{C}$ for $6 \mathrm{~h}$ before is used in experiments. Preliminary experiments were conducted to optimize general pattern for $\mathrm{NH}_{4}{ }^{+}$ion removal from aqueous solution; $\mathrm{pH}$ of solution, dosage of adsorbent and shaking time. The ion exchange of $\mathrm{NH}_{4}{ }^{+}$ion on the zeolite was carried out using batch method. The batch experiments were conducted by mixing $0.5 \mathrm{~g}$ adsorbent with $50 \mathrm{ml}$ of ammonia solution in the range of $1-30 \mathrm{mg} / \mathrm{l}$. Analytical grade ammonium chloride salt $\left(\mathrm{NH}_{4} \mathrm{Cl}\right)$ and deionised water were used in the preparation of the stock $\mathrm{NH}_{4}{ }^{+}$solutions. The stock solutions was diluted to prepare for working solutions.

The conical flasks containing sorbate and sorbent were placed in shaker and shaken at room temperature. After equilibrium time, samples were filtered through whatman 42 filter paper. The equilibrium concentrations of ammonium were determined analyzing samples after filtration by using the colorimetric method with the Nessler solution. The removal efficiency (\%) and the amounts of exchanged $\mathrm{NH}_{4}{ }^{+}$ion $\left(\mathrm{Q}_{\mathrm{e}}\right)$ by the zeolite were calculated using Eqs. (1) and (2), respectively

$$
\begin{aligned}
& R(\%)=\frac{\left(C_{o}-C_{e}\right) \cdot 100}{C_{0}} \\
& Q_{e}=\frac{\left(C_{o}-C_{e}\right) \bullet V}{m}
\end{aligned}
$$

Where $Q_{e}$ is the amount of exchanged ammonium ions $(\mathrm{mg} / \mathrm{g}), \mathrm{C}_{0}$ and $\mathrm{C}_{\mathrm{e}}$ are the initial and equilibrium concentrations of ammonium in solution $(\mathrm{mg} / \mathrm{L})$, respectively. $V$ is the solution volume $(\mathrm{L})$ and $\mathrm{m}$ is the adsorbent weight $(\mathrm{g})$.

\section{RESULTS AND DISCUSSION}

For the purpose of an increase in the cation exchange capacity of natural zeolite were activated by solution $0.1 \mathrm{~N} \mathrm{HCl}$ and $0.1 \mathrm{~N} \mathrm{NaCl}$. Two replicates of $10 \mathrm{~g}$ of natural zeolites were shaken with $200 \mathrm{ml}$ of $0.1 \mathrm{~N} \mathrm{HCl}$ and $\mathrm{NaCl}$ salt for 7 hours. The exchanged forms washed with distilled water and dry in an electric oven at $105^{\circ} \mathrm{C}$ for 2-3 hours before using adsorption purpose.

The adsorbed amounts were determined using equation 1. The amounts of adsorption were determined $0.25 \mathrm{mg} / \mathrm{g}, 0.48 \mathrm{mg} / \mathrm{g}$ and $0.63 \mathrm{mg} / \mathrm{g}$ as a natural zeolite, the zeolite that formed its exchangeable cations to $\mathrm{Na}$ and the zeolite that formed its exchangeable cations to $\mathrm{H}$, respectively( Figure 2). 


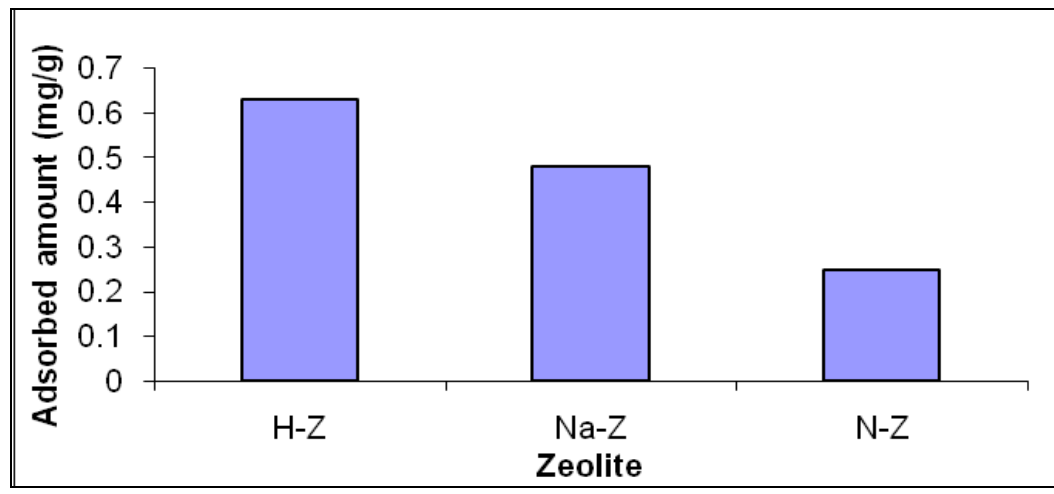

Figure 2 - The effect of exchangeable cation ( $N-Z$ is natural zeolite, $N a-Z$ is $N a$ form zeolite, $H-Z$ is $H$ form zeolite, $\mathrm{NH}_{4}{ }^{+}$ion concentration $10 \mathrm{mg} \mathrm{L}$; adsorbent dosage $0.5 \mathrm{~g}$; shaking time 180 min; temperature $20^{\circ} \mathrm{C}$ ).

\subsection{Effect of $\mathrm{pH}$}

The removal of $\mathrm{NH}_{4}{ }^{+}$ion from aqueous solution using the natural zeolite was studied at $\mathrm{pH}$ values 210 , with the initial concentration of ammonia of $10 \mathrm{mg} / \mathrm{L}$, and the obtained data are given in Figure 3 .

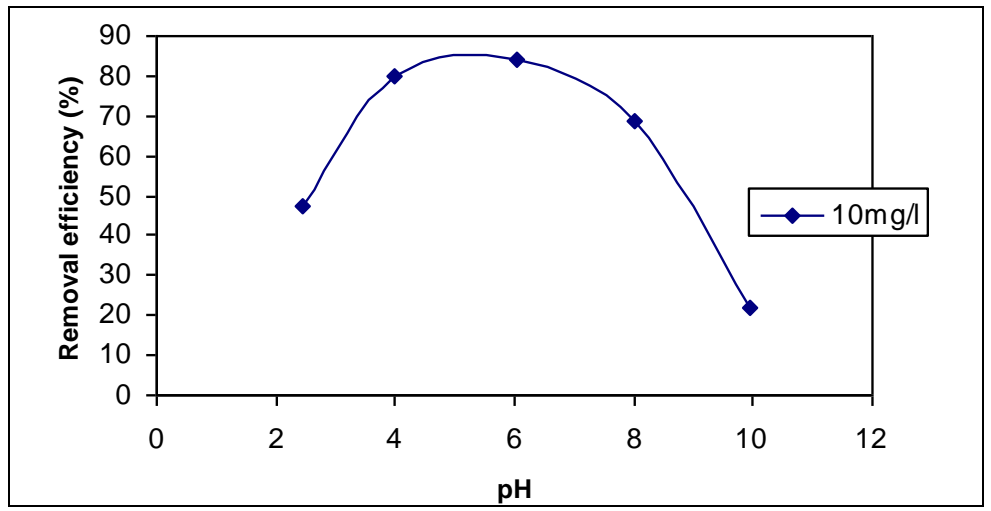

Figure 3 - The effect of $\mathrm{pH}$ on $\mathrm{NH}_{4}^{+}$ion removal using the natural zeolite

$\left(\mathrm{NH}_{4}^{+}\right.$ion concentration $10 \mathrm{mg} \mathrm{L}^{-}$; adsorbent dosage $0.5 \mathrm{~g}$; shaking time $180 \mathrm{~min}$; temperature $\left.20^{\circ} \mathrm{C}\right)$.

The removal efficiency increase with increase of $\mathrm{pH}$ from 2 to 6 , reaching a maximum value at $\mathrm{pH} \mathrm{6}$, and then decreased at $\mathrm{pH} 10$. The decrease in the $\mathrm{NH}_{4}{ }^{+}$removal efficiency after $\mathrm{pH} 6$ may be due two factors: (a) partial dissolution of the natural zeolite; (b) the conversion of $\mathrm{NH}_{4}^{+}$into $\mathrm{NH}_{3}$ specimen [7].

\subsection{Effect of adsorbent dosage}

The effect of adsorbent dosage on removal efficiency of $\mathrm{NH}_{4}{ }^{+}$ion was studied with $0.1,0.3,0.5$, 1.0 and $1.5 \mathrm{~g}$ zeolite, and with initial concentration of ammonia of $10 \mathrm{mg} / \mathrm{L}$, and the results obtained were given in Fig 3 and 4.

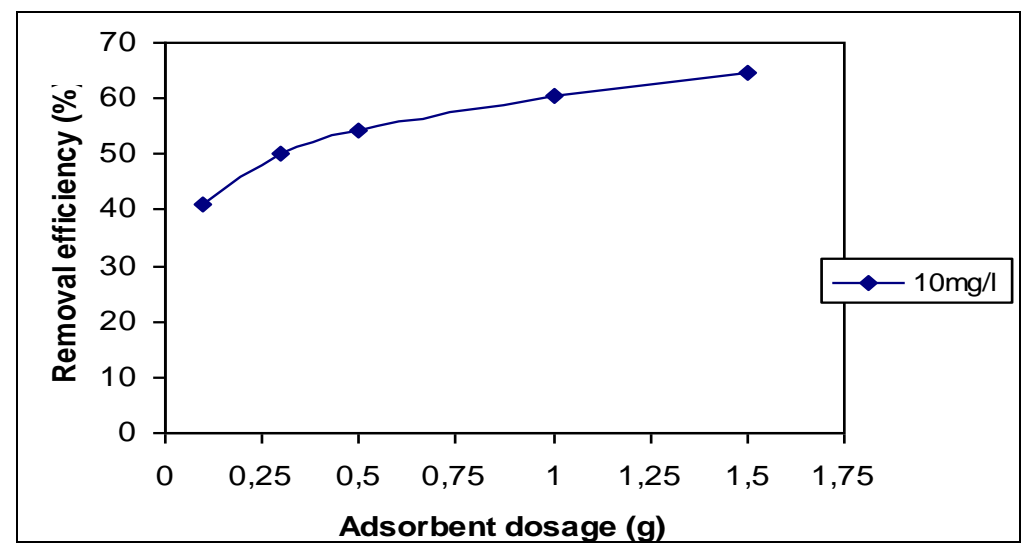

Figure 4 - The effect of adsorbent dosage on $\mathrm{NH}_{4}^{+}$ion removal using the natural zeolite $\left(\mathrm{NH}_{4}{ }^{+}\right.$ion concentration $10 \mathrm{mg} \mathrm{L}$, shaking time $180 \mathrm{~min}$, temperature $20^{\circ} \mathrm{C}$ ) 
The removal efficiency of $\mathrm{NH}_{4}^{+}$ions by the zeolite increased with increasing the amount of zeolite, and a plateau occurred at $1.0 \mathrm{~g}$ of adsorbent. Fig. $3 \& 4$ also indicated that the $\mathrm{NH}_{4}{ }^{+}$ion removal did not change at higher amounts of adsorbent than $1.0 \mathrm{~g}$. This may be attributed to the formation of aggregates at higher solid/liquid ratio or precipitation of particles.

\subsection{Adsorption and Langmuir isotherm}

Two important physiochemical aspects for the evaluation of the adsorption process as a unit operation are the equilibria of the adsorption and the kinetics. Equilibrium studies give the capacity of the adsorbent [9]. The equilibrium relationships between adsorbent and adsorbate are described by adsorption isotherms, usually the ratio between the quantity adsorbed and that remaining in solution at a fixed temperature at equilibrium. There are two common types of adsorption isotherms: Langmuir adsorption isotherms and Freundlich adsorption isotherms

Irving Langmuir, an American chemist who was awarded the Nobel prize for chemistry in 1932 for "his discoveries and researches in of surface chemistry", developed a relationship between the amount of gas adsorbed on surface and the pressure of gas. Such equations are now referred as Langmuir adsorption isotherms, a theoretical adsorption isotherm in the ideal case. The
Langmuir adsorption isotherm is often used for adsorption of a solute from a liquid solution. The Langmuir adsorption isotherm is perhaps the best known of all isotherms describing adsorption and is often expressed as [10].

$$
Q=Q \max \frac{K \cdot C}{1+K C} Q \max \frac{C}{\frac{1}{K+C}}=Q \max \frac{C}{a+C}
$$

Qmax - maximum adsorption capacity $(\mathrm{mg} / \mathrm{g})$

$\mathrm{K}$ - an adsorption constant $(\mathrm{L} / \mathrm{g})$ and $\mathrm{a}=1 / \mathrm{K}$

$\mathrm{C}$ - metal initial concentration

Then, by raising both members of the previous equation at -1 it is possible to obtain following expression:

$$
\frac{1}{Q}=\frac{a+C}{Q \max \cdot C}=\left(\frac{a}{Q \max }\right) \cdot \frac{1}{C}+\frac{1}{Q \max }
$$

Considering the axes $y=1 / Q$ and $x=1 / C$, it is possible to have a linear function of the type $y=d x+b$, where $d=a / Q \max$ and $b=1 / Q \max$. Then $1 / Q$ max is equal to the intercept of this straight line on the vertical axis, while $a / Q$ max is the slope of the straight-line equation. The correlation coefficient $\left(R^{2}\right)$ and $b$ and $d$ values have been obtained from the linear equation (fig. 5). By this procedure $\mathrm{Q}$ max and a have been derived for each tracer in each soil.

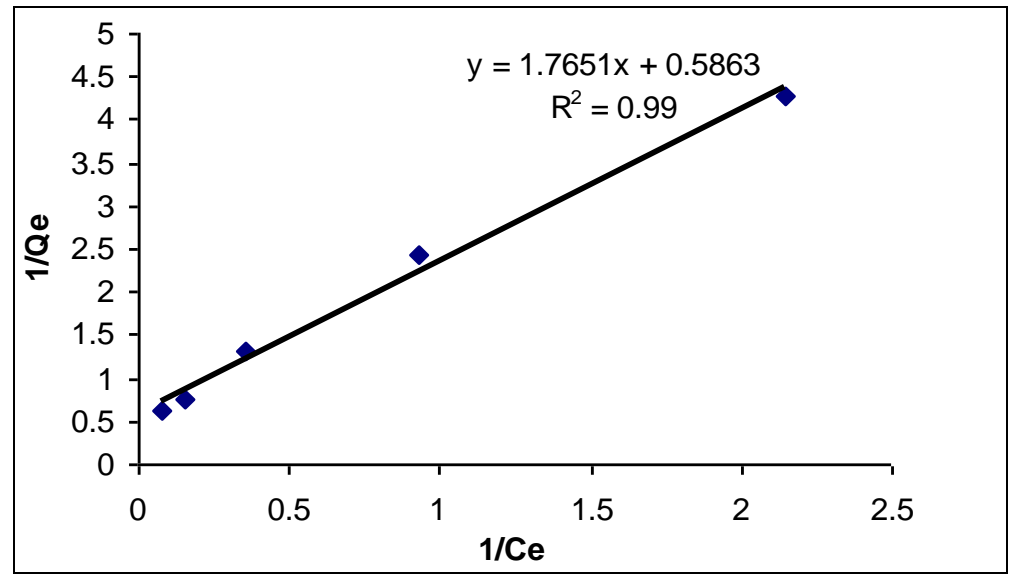

Figure 5 - Langmuir adsorption isotherms of ammonium ion on zeolite

\section{Freundlich isotherm}

Herbert Max Finley Freundlich, a German physical chemist, presented an empirical adsorption isotherm for non ideal systems in 1906. The Freundlich isotherm is the earliest known relationship describing the adsorption equation and is often expressed as [10] :

$$
Q_{e}=K_{f} \cdot C_{e}^{\frac{1}{n}}
$$

where: $Q_{e}$ - is the adsorption density $(\mathrm{mg}$ of adsorbate per $\mathrm{g}$ of adsorbent)

$\mathrm{C}_{e^{-}}$is the concentration of adsorbate in solution (mg/l)

$\mathrm{K}_{\mathrm{f}}$ - and $\mathrm{n}$ are the empirical constants dependent on several environmental factors and $n$ is greater than one. This equation is conveniently used in the linear form by taking the logarithm of both sides as:

$$
\log \left(Q_{e}\right)=\log \left(K_{f}\right)+\frac{1}{n} \log \left(C_{e}\right)
$$


A plot of InCe against In Qe yielding a straight line indicates the confirmation of the Freundlich isotherm for adsorption (fig. 6).

The constants can be determined from the slope and the intercept (Table 2).
The isotherms are compared based on the parameter values with experimental data $30^{\circ} \mathrm{C}$ as shown in Fig. 7. Freundlich isotherm shows better fit than Langmuir isotherm.

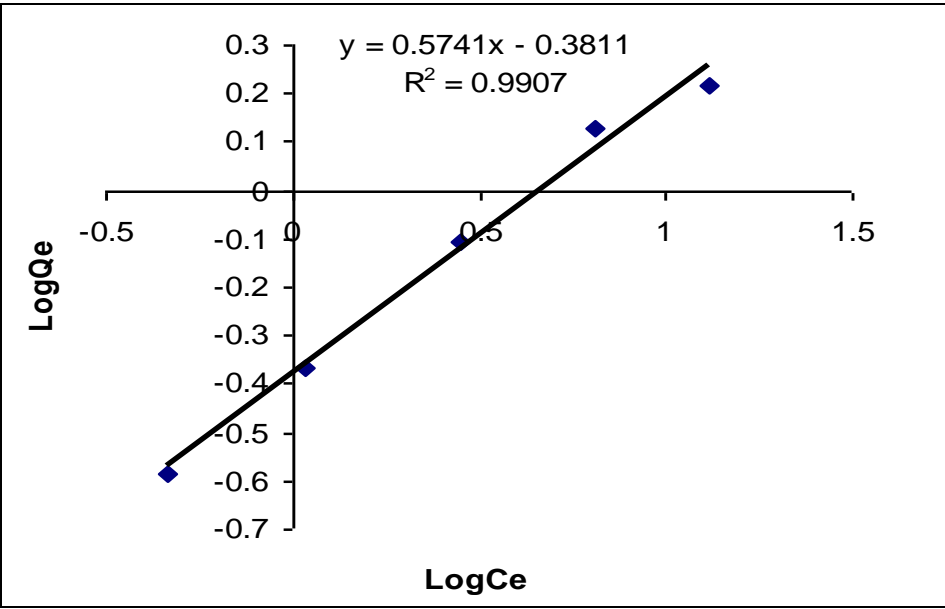

Figure 6 - Linear Freundlich isotherm of ammonium ion by zeolite

Table 2 - Langmuir constant and Freundlich constant

\begin{tabular}{|c|c|c|c|c|c|}
\hline $\mathrm{T}$ & \multicolumn{3}{|c|}{ Langmuir constant } & \multicolumn{3}{c|}{ Freundlich constant } \\
\cline { 2 - 6 }$\left(^{(0} \mathrm{C}\right)$ & $\mathrm{Q}_{\max }(\mathrm{mg} / \mathrm{g})$ & $\mathrm{K}(\mathrm{l} / \mathrm{mg})$ & $\mathrm{K}_{\mathrm{f}}(\mathrm{mg} / \mathrm{g})$ & $\mathrm{n}$ & $\mathrm{R}^{2}$ \\
\hline 30 & 1.64 & 0.345 & 0.4158 & 1.74 & 0.9907 \\
\hline
\end{tabular}

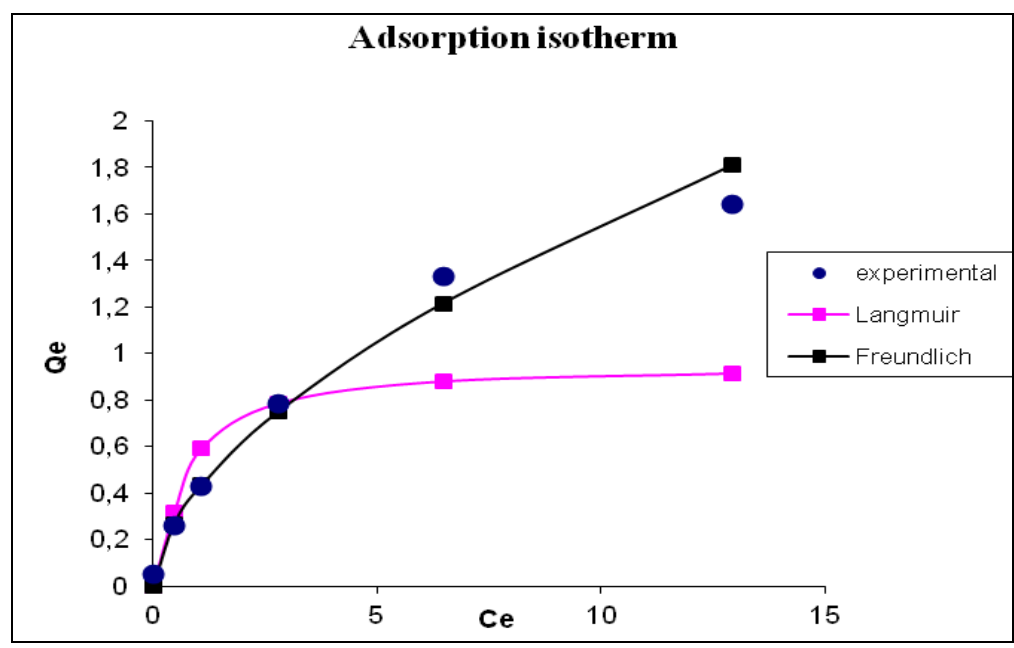

Figure 7 - Adsorption isotherms at $\mathrm{pH} 6.0$ and $\mathrm{T}=-30^{\circ} \mathrm{C}$

\subsubsection{Effect of the initial ammonium concentrations}

Ammonium exchange by natural clinoptilolite was studied at different initial $\mathrm{NH}_{4}^{+}$concentrations in the range of $5 \mathrm{mg} / \mathrm{L}-30 \mathrm{mg} / \mathrm{L}$. As shown in Fig.3, ammonium exchange capacity increased with increasing of the initial $\mathrm{NH}_{4}^{+}$concentration and this is the result of in increase in the driving force [8]. For lower initial concentration of the $\mathrm{NH}_{4}^{+}$, equilibrium time was lower than for higher concentrations because of the increased competition for the active sites with increasing in of $\mathrm{NH}_{4}{ }^{+}$ concentration. This may be an indication that the ion-exchange surface becomes increasingly saturated with ammonium ion.

\section{Effect of contact time}

Fig.8 show that ammonium ion removal by clinoptilolite was very fast within the initial $15 \mathrm{~min}$, and thereafter did not change since equilibrium is attained. 


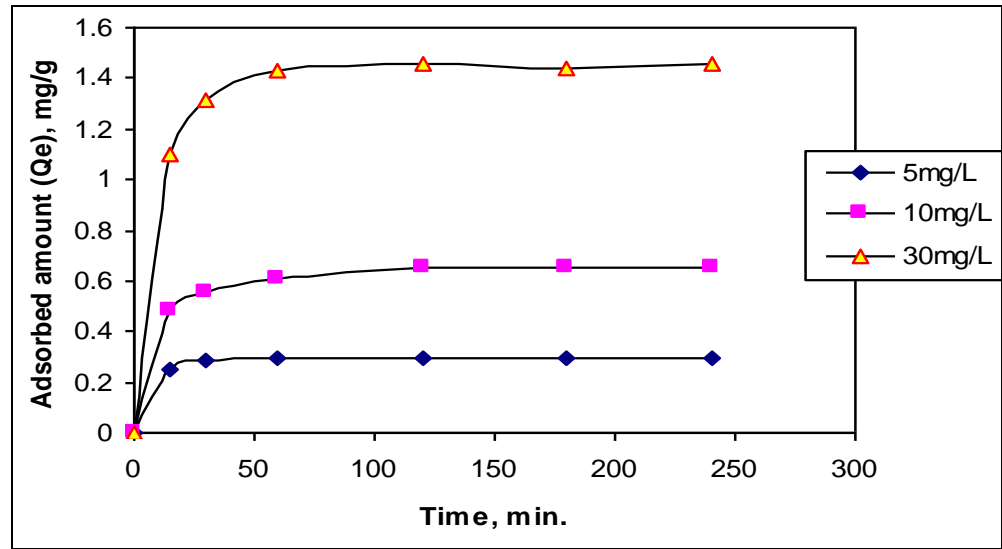

Figure 8 - The effect of contact time on $\mathrm{NH}_{4}^{+}$ion removal using the natural zeolite $\left(\mathrm{NH}_{4}^{+}\right.$ion concentrations: $5 \mathrm{mg} \mathrm{L}^{-}, 10 \mathrm{mg} \mathrm{L}^{-}$and $30 \mathrm{mg} \mathrm{L}^{-}$; adsorbent dosage: $0.5 \mathrm{~g} ; \mathrm{pH}: 6$; temperature: $20^{\circ} \mathrm{C}$ )

\section{CONCLUSION}

The experimental parameters such as solution $\mathrm{pH}$, contact time, and adsorbent dosage influenced $\mathrm{NH}_{4}{ }^{+}$ion removal from aqueous system by the zeolite. Freundlich model yield a much better fit than that of the Langmuir model.

Based on the results, it can be concluded that the natural Mongolian (Urgun) zeolite is suitable for $\mathrm{NH}_{4}{ }^{+}$ion removal from aqueous solution. Moreover, it can be recommended for wastewater treatments and agricultural purposes in terms of sustainability of environmental quality.

\section{REFERENCES}

[1] J.B.Dixon, S.B.Weed (1989) Mineral soil Environment, SSSSA Pub.Inc., Madison, WI, p.585-610.

[2] Z.L.He, D.V.Calvert, A.K.Alva (2002) Clinoptilolite zeolite and cellulose amendment to reduce ammonia volatilization in a calcareous sandy soil, Plant Soil, 247, 253-260.

[3] M.Amon, M.Dobeis, R.W.Sneath, V.R.Philips, T.H.Misselbrook, B.F.Pain (1997) A farm-scale study on the of clinoptilolite zeolite and debodoras for reducing odor and ammonia emission from broiler houses, Bioresour. Technol.,61, 229-267.

[4] A.Chlopecka, D.C.Adriano (1997) Influence of zeolite, apatite and Fe-oxide on $\mathrm{Cd}$ and $\mathrm{P}$, uptake by crops, Sci. Total Environ., 207, 195-206.

[5] T.S.Perrin, J.L.Boettinger, D.T.Drost, J.M.Noron (1986) Decreasing nitrogen leaching from study soil with ammonium loaded clinoptilolite, J.Environ. Qual.,27, 656-663.

[6] US-EPA (1971) Optimisation of ammonia removal by ion exchange using clinoptilolite, EPA report, Project-17080.

[7] E.Maranon, M.Ulmanu, Y.Fernander, I.Anger (2006) Removal of ammonium ion from aqueous solution with volcanic tuff, J.Hazard. Mater., 136(1), 502512.

[8] Y.S.Ho, T.H.Chiang, Y.M.Hsueh (2005) Removal of basic dye from aqueous solution using tree fern as a biosorbent, Process Biochem., 40, 119-124.

[9] G.M.Haggerty, R.S.Bowman (1994) Sorption of chromate and other inorganic anions by organo zeolites, Environ. Sci. Technol., 28, 452-458.

[10] T.J.Casey (1997) Unit Treatment Processes in Water and Wastewater Engineering, John Wiley and Sons Ltd, England, p.113-114

\section{IZVOD}

\section{ISPITIVANJE EFEKTA RELEVANTNIH PARAMETARA MONGOLSKIH PRIRODNIH ZEOLITA ZA UKLANJANJE AMONIJUM JONA IZ VODENOG RASTVORA}

$U$ radu je ispitivan potencijal prirodnog zeolita iz ležišta u Mongoliji za uklanjanje amonijum jona iz vodenih rastvora. Razmatran je uticaj različitih parametara, kao što su pH rastvora, količina adsorbe nta, vreme kontakta I početna koncentracija amonijum jona, na stepen uklanjanja amonijum jona. Rezultati su pokazali da $\mathrm{pH}$ rastvora utiče na efikasnost uklanjanja amonijum jona. Uklanjanje amonijum jona je brz process koji se dešava u prvih 15 min kontakta, a kapacitet adsorpcije klinoptilolita raste sa porastom početne koncentracije amonijum jona. Kod određivanja adsorpcionih izotermi, Langmir i Frojndlih modeli su primenjeni za fitovanje eksperimentalnih rezultata, i najbolje slaganje je postignuto sa Frojndlih-ovim modelom. Na osnovu dobijenih rezultata može se zaključiti da je prirodni zeolit iz ležišta u Mongoliji pogodan za uklanjanje $\mathrm{NH}_{4}^{+}$jona iz otpadnih voda.

Ključne reči: klinoptilolit, prirodni zeoliti, amonijum jon, vodeni rastvor.

Naučni rad

Rad primljen: 24. 10. 2016.

Rad prihvaćen: 26. 11. 2016.

Rad je dostupan na sajtu: www.idk.org.rs/casopis 